\title{
PENINGKataN hasIL BelajaR SISWA DI SMPN 3 GEPU \\ MELALUI APLIKASI QUIPPER SCHOOL
}

\author{
IDA MUNARTI \\ SMP Negeri 3 Cepu \\ idamunarti69@gmail.com
}

Pertama Diterima: 12 September 2020

Bukti Akhir Diterima: 30 Desember 2020

\begin{abstract}
Abstrak
Penelitian ini bertujuan untuk memperoleh data dan informasi mengenai peningkatan hasil belajar siswa pada mata pelajaran Bahasa Indonesia di kelas IX SMP Negeri 3 Cepu pada masa pandemikCovid-19 dengan menggunakan media Quipper School.Penelitian ini juga menentukan media yang tepat untuk pembelajaran jarak jauh (PJJ). Metode penelitian ini menggunakan Quasi experiment dengan bentuk kontrol grup pretes and postes design. Populasi penelitian ini adalah siswa kelas IX SMP Negeri 3 Cepu yang terdiri 8 kelas. Jumlah sampel adalah 31 siswa kelas IX D sebagai kelas eksperimen dan kelas IX B sebagai kelas kontrol sebanyak 31 siswa melalui sample acak. Instrumen yang digunakan adalah angket untuk mengetahui apakah siswa sudah mengenal dan menggunakan media quipper school sebagai pembelajaran alternatif. Data yang diperoleh dianalisis secara deskriptif. Hasil analisis pretes dan postes menunjukan ada peningkatan rata-rata hasil belajar Bahasa Indonesia dari nilai 62 meningkat menjadi 85 setelah menggunakan media Quipper School
\end{abstract}

Kata Kunci : hasil belajar, media quipper school, pembelajaran jarak jauh

\begin{abstract}
This study aims to obtain data and information regarding the improvement of student learning outcomes in Indonesian language subjects in class IX of SMP Negeri 3 Cepu during the Covid 19 pandemic using Quipper School media. This study also determines the appropriate media for distance learning (PJJ). This research method used Quasi experiment with control group pretest and posttest design. The population of this study were students of class IX SMP Negeri 3 Cepu which consisted of 8 classes. The number of samples was 31 students of class IX D as the experimental class and class IX B as the control class as many as 31 students through a random sample. The instrument used was a questionnaire to find out whether students were familiar with and used the quipper school media as an alternative learning. The data obtained were analyzed using inferential statistics. The results of the pretest and posttest analysis showed that there was an increase in the average Indonesian learning outcomes from a value of 61.94 to 78.90 after using Quipper School media.
\end{abstract}

Keywords: Learning Outcomes, Quipper School Media, Distance Learning

\section{PENDAHULUAN}

Sesuai Surat Edaran Menteri Pendidikan dan Kebudayaan Republik Indonesia Nomor 15 tahun 2020 tentang Pedoman Penyelenggaraan Belajar dari Rumah dalam Masa Darurat Penyebaran Corona Virus Deseas (COVID-19) (Hukum et al., 2020). Hal ini membuat semua pembelajaran dilakukan dengan online atau dikenal dengan Pembelajaran Jarak Jauh atau Belajar Dari Rumah. Namun, dalam hal ini guru memberikan andil dalam penyelenggaraan PJJ. Guru dituntut tidak hanya mentransfer ilmu tetapi mengatur strategi dan media dalam pembelajaran jarak jauh. 
Peran guru sangat penting dalam penyelenggaraan pembelajaran jarak jauh untuk mengatur strategi dan menentukan media yang tepat selama masa pandemi Covid-19. Pembelajaran jarak jauh memerlukan media pembelajaran dan kreativitas agar pembelajaran dapat terlaksana dengan baik (Aprilianto \& Putra, 2020:4). Banyak media pembelajaran online yang dapat diterapkan dalam dunia pendidikan. Menurut pendapat Molinda yang dikutip Arizona (2020:66) pembelajaran online menghubungkan siswa dengan sumber belajarnya yang secara fisik terpisah namun dapat saling berkomunikasi, berinteraksi (secara langsung / synchronous dan secara tidak langsung/ asynchronous). Kelebihan menggunakan pembelajaran online adalah pembelajaran menjadi mandiri dan interaktivitas yang tinggi mampu meningkatkan daya ingat, memberikan pengalaman belajar dengan teks audio, video conference untuk berkomunikas secara langsung.

Media pembelajaran online dapat digunakan untuk memberikan pembelajaran dari rumah atau Pembelajaran Jarak Jauh (PJJ). Pelaksanaan belajar dari rumah ini diharapkan tidak hanya difokuskan pada pencapaian akademik saja, tetapi juga pada pembelajaran kecakapan hidup. Kegiatan belajar dari rumah juga diharapkan agar siswa mendapatkan pengalaman belajar yang bermakna.

Media yang tepat menjadi hal mutlak untuk meningkatkan hasil belajar siswa. Media Quipper School menyediakan bahan ajar yang menarik dan sesuai dengan Kurikulum 2013. Siswa mudah mengulang bahan ajar kapan pun dan di mana saja. Guru dan siswa dapat berdiskusi melalui fasilitas pesan dalam aplikasi Quipper School, sehingga membuat siswa menjadi aktif. Ada dua portal dalam media Quipper Schoolyaitu portal guru dan siswa, sehingga kapan pun guru bisa memberi tugas dengan mudah dan siswa dapat mengerjakan tugas pada saat itu juga.

Media ini merupakan salah satu media pembelajaran yang interaktif dan efektif secara online. Pada aplikasi Quipper School ini guru berperan seperti biasanya sebagai fasilitator dalam mengelola materi, melaksanakan tes atau ujian, serta melihat perkembangan siswa. Siswa pun dengan mudah mengerjakan tugas atau ujian secara online dan dapat mengetahui umpan balik secara langsung.Siswa merasa senang karena penyajian materi pelajaran yang menarik serta mudah untuk dipahami melalui alat komunikasi yang mereka miliki, seperti laptop dan gawai (Hudaidah, 2019:39.) Aplikasi Quipper School juga dapat diakses secara gratis melalui paket Ilmupedia.

Penelitian sebelumnya didapatkan bahwa Quipper School dapat meningkatkan hasil belajar siswa, mengingat siswa dapat belajar sambil bermain sehingga tidak ada tekanan. Quipper School juga dapat meningkatkan baik proses maupun hasil belajar siswa karena mereka belajar tanpa tekanan (Karmila, 2017:121). Peneliti mencari media yang benar-benar dapat menciptakan suasana pembelajaran yang menarik dan menyenangkan siswa melalui suatu proses aktivitas siswa sehingga pembelajaranakan lebih santai, tidak membosankan dan menimbulkan persaingan sehat untuk memperoleh nilai yang setinggi-tingginya. Media Quipper School merupakan sarana pembelajaran yang penyampaiannyaselalumenarik dan up to date dalam memberikan stimulus kepada siswa, sehingga siswa akan dengan sendirinya merasa tertarik dengan pembelajaran bahasa Indonesia. Dengan demikian, kemandirian belajar siswa akan terbentuk pada diri masing-masing siswa sehingga hasil belajar pun menjadi meningkat.

Berdasarkan uraian tersebut, maka penelitian ini dilakukan dengan maksud untuk mengetahui penggunaan media pembelajaran online dalam meningkatkan hasil belajar siswa di 
SMP Negeri 3 Cepu pada masa pandemi Covid-19 ini. Selain itu, penelitian ini juga bertujuan untuk mengetahui media yang tepat bagi siswa di masa pandemi Covid-19 ini. Dengan media yang tepat diharapkan siswa tidak merasa bosan belajar di rumah, kemandirian untuk belajar juga tinggi karena mereka senang belajar dengan menggunakan media yang tepat. Dengan siswa tetap belajar walaupun berada di rumah maka hasil belajar pun akan meningkat. Tak kalah pentingnya penelitian ini juga untuk memberikan tinjauan secara umum terkait pembelajaran online pada masa pandemi Covid-19.

\section{METODE PENELITIAN}

Metode penelitian ini adalah penelitian kuantitatif dengan menggunakan eksperimen semu. Menurut (Barlian, 2016:60) metode yang mengunakan eksperimen dapat menguji hipotesis sebab akibat. Desain penelitian yang digunakan dalam penelitian ini terdapat group pretes sebelum mendapat perlakuan dan postest setelah mendapat perlakuan. Maka hasil penelitian akan lebih akurat, karena membandingkan dengan sebelum mendapat perlakuan. Menurut Sugiyono (2012: 50) Ada dua variabel pada penelitian ini yaitu variabel bebas (X) dan variabel terikat (Y). Variabel bebas (X) dalam penelitian ini menggunakan aplikasi Quipper School, sedangkan variabel kedua merupakan variabel terikat yaitu hasil belajar siswa kelas IX SMP Negeri 3 Cepu.

Populasi pada penelitian ini adalah seluruh siswa kelas IX di SMP Negeri 3 Cepu yang terdiri atas 8 kelas dengan jumlah 249 siswa. Sampel yang digunakan dalam penelitian ini adalah kelas IX D yang berjumlah 31 siswa sebagai kelas eksperimen dan kelas IX B yang berjumlah 31 siswa sebagai kelas kontrol. Total seluruh jumlah sampel 62 siswa. Proses pembelajaran pada kelas eksperimen akan menggunakan media pembelajaran Quipper school, sedangkan kelas kontrol menggunakan media Whats App Group untuk pemberian tugas. Waktu pengambilan penelitian bulan Maret sampai dengan April 2020 saat wabah pandemi Covid-19. Pengambilan sampel berdasarkan cara random sampling.

Teknik pengumpulan data dalam penelitian ini menggunakan tes dan kuisioner. Tes yang dilakukan adalah pretest dan post-test. Tes yang dilaksanakan berupa pretest 20 soal dan post-test 25 soal pilihan ganda untuk mengetahui perubahan hasil belajar siswa pada saat sebelum dan sesudah belajar dengan menggunakan media Quipper School. Adapun kuisioner untuk memberikan pertanyaan atau pernyataan tertulis kepada siswa untuk mengetahui sikap dan perilaku siswa terhadap proses pembelajaran dengan media Quipper School.

Analisis data yang digunakan dalam penelitian ini adalah analisis statistik inferensial. Sebelum menguji hipotesis, terlebih dahulu menghitung rata-rata, varians dan simpangan baku, setelah itu data diuji normalitas dan homogenitas.

\section{HASIL PENELITIAN DAN PEMBAHASAN}

\section{Hasil Penelitian}

Pembelajaran jarak jauh pada masa pandemi Covid-19 ini SMP Negeri 3 Cepu menggunakan moda daring. Dengan pembelajaran daring siswa dapat belajar seperti biasanya, 
mengerjakan tugas, mendapatkan materi dengan tetap berada di rumah. Namun pembelajaran daring tidak berjalan sepenuhnya. Ada beberapa siswa yang mengganggap bahwa pembelajaran daring menyulitkan dan lebih suka pembelajaran tatap muka. Siswa merasa bosan setiap hari ada banyak tugas yang harus diselesaikan. Oleh sebab itu, peneliti mengunakan media yang membuat siswa tidak merasa jenuh saat belajar di rumah.

Hasil pembahasan pada penelitian ini dari analisis data tentang penggunaan media aplikasi Quipper school untuk meningkatkan hasil belajar siswa pada mata pelajaran Bahasa Indonesia kelas IX SMP Negeri 3 Cepu, pada masa pandemik Covid-19 yang akan dipaparkan di bawah ini.

Hasil yang diperoleh dari penelitian ini dilaksanakan dua siklus masing-masing siklus ada dua pertemuan. Tahapan penelitian yang dilakukan sebagai berikut.

1) Tahap perencanaan, peneliti merencanakan skenario pembelajaran.

2) Tahap pelaksanaan, yaitu untuk kelas kontrol memberikan tugas atau latihan menggunakaan whats app dan kelas eksperimen menggunakan aplikasi Quipper School. Untuk instruksi pelaksanaan kedua kelas tersebut melalui Whats App.

3) Tahap observasi, peneliti mengamati hasil pekerjaan siswa.

4) Refleksi.

Tahap-tahap ini juga dilakukan intuk pertemuan yang kedua dengan perubahan sedikit setelah mengadakan refleksi. Semua pelaksanaan penelitian ini dilaksanakan di rumah masingmasing siswa.

Berdasarkan deskripsi keaktifan belajar pada kondisi awal sebelum diadakan tindakan dengan menggunakan aplikasi Quipper School. Peneliti melakukan pengamatan melalui media Whats App Grup siswa yang kurang aktif 11 siswa (36,48.\%), Cukup aktif 8 siswa (25,80 \%) dan yang aktif 12 siswa (38,70\%). Ini berarti siswa belum sepenuhnya mengikuti pembelajaran jarak jauh dengan maksimal. Hal ini dikarenakan siswa kurang berminat apabila pembelajaran disampaikan melalui Whats App Grup. Setelah diadakan tindakan dengan menggunakan aplikasi Quipper School siswa yang aktif $22(70,96)$, cukup aktif $3(9,67 \%)$, dan yang kurang aktif 5 siswa $(16,12 \%)$

Kategori tingkat keaktifan belajar siswa sebagai berikut.

1. $85 \%-100 \%=$ Sangat Tinggi

2. $69 \%-84 \%=$ Tinggi

3. $53 \%-68 \%=$ Cukup

4. $37 \%-52 \%=$ Rendah

5. $20 \%-36 \%=$ Sangat Rendah

Jadi, dari hasil observasi menurut katagori tersebut sebelum diadakan tindakan termasuk kategori rendah. Setelah dilakukan refleksi untuk mengoreksi kelemahan dan kendala yang terjadi pada silkus 1 dan siklus 2 kemudian mencari solusi yang nanti akan diterapkan pada pertemuan berikutnya dengan harapan hasilnya mengalami peningkatan. 
Tabel 1 Rentang Predikat Berdasarkan KKM

\begin{tabular}{|c|c|c|c|}
\hline No & Rentang Nilai & Predikat & Keterangan \\
\hline 1 & $92-100$ & Sangat Baik & Tuntas \\
\hline 2 & $83-91$ & Baik & Tuntas \\
\hline 3 & $75-82$ & Cukup & Tuntas \\
\hline 4 & $<75$ & Kurang & Belum Tuntas \\
\hline
\end{tabular}

Tabel 2 Rekapitulasi Hasil Penilaian Siklus 1 dan 2

\begin{tabular}{|l|c|c|c|c|}
\hline \multirow{2}{*}{ Keterangan } & \multicolumn{2}{|c|}{ Kelas Kontrol } & \multicolumn{2}{c|}{ Kelas Eksperimen } \\
\cline { 2 - 5 } & \multicolumn{2}{|c|}{ Pemanfaatan WAG } & \multicolumn{2}{c|}{ Quipper School } \\
\cline { 2 - 5 } & Siklus 1 & Siklus 2 & Siklus 1 & Siklus 2 \\
\hline Tuntas & 2 & 13 & 11 & 26 \\
\hline Belum Tuntas & 29 & 18 & 20 & 5 \\
\hline Nilai TT & 80 & 85 & 80 & 96 \\
\hline Nilai TR & 30 & 40 & 40 & 68 \\
\hline Rata-rata & 52 & 70 & 58 & 85 \\
\hline
\end{tabular}

Berdasarkan Tabel 2 terlihat bahwa hasil belajar siswa dari kelas control yang menggunakan whats app group pada siklus 1 pada penilaian pretes rata-rata 52 dengan nilai tertinggi 80 dan terendah 30 siswa yang tuntas 2 sedangkan yang belum tuntas 29 siswa, untuk siklus 2 penilaian postes (masih menggunakan whats app) rata-rata 70 dengan nilai tertinggi 85 dan terendah 40, siswa yang tuntas 13, siswa yang belum tuntas 18 .

Untuk kelas eksperimen menggunakan Quipper School pada siklus 1 penilaian pretest ratarata 58 dengan nilai tertinggi 80 dan terendah 40 siswa yang tuntas 11 yang belum tuntas 20 siswa. Untuk penilaian postes rata-rata 85 dengan nilai tertinggi 96 dan terendah 68 , siswa yang tuntas 26 , dan belum tuntas 5 siswa.

\section{Pembahasan}

\section{Pemanfaatan Aplikasi Quipper School untuk Meningkatkan Hasil Belajar Siswa di SMP Negeri Cepu}

Kelas yang digunakan sebagai kelas eksperimen pada penelitian ini adalah kelas IX D pada mata pelajaran Bahasa Indonesia dengan jumlah 31 siswa. Penelitian ini dilakukan sebanyak 5 kali. Tes pertama dilaksanakan sebagai pretes, eksperimen selanjutnya kedua sampai dengan keempat dilaksanakan dengan media Quipper School, selanjutnya pada eksperimen terakhir kelima dilaksanakan post-test. Berdasarkan perolehan skor yang telah dipaparkan sebelumnya memberikan gambaran bahwa skor yang diperoleh siswa yang menggunakan media Quipper School hasil belajarnya lebih tinggi dibandingkan dengan siswa yang tidak menggunakan media Quipper 
School.

Penelitian ini dilaksanakan selama rentang waktu satu setengah bulan dengan 5 kali pertemuan setelah pemberian pretest di masing-masing kelas. Kelas IX D sebagai kelas eksperimen menggunakan tes dengan media Quipper School untuk mengetahui perkembangan hasil belajar. Untuk kelas kontrol diberikan tugas dengan WhatsApp Group.

Tabel 3 Hasil Belajar Siswa Sebelum Perlakuan ( Pretest )

\begin{tabular}{|c|c|c|c|}
\hline No & Statistik Deskriptif & Kelas Kontrol & Kelas Eksperimen \\
\hline 1 & Jumlah sampel & 31 & 31 \\
\hline 2 & Skor tertinggi & 80 & 80 \\
\hline 3 & Skor terendah & 30 & 40 \\
\hline 4 & Rata-rata & 52 & 58 \\
\hline
\end{tabular}

Sesuai dengan hasil prestes siswa kelas IX D sebagai kelas eksperimen menunjukkan bahwa nilai rata-rata hasil belajarnya masih rendah yaitu 62 dan masih digolongkan kategori rendah dengan nilai tertinggi 90 dan nilai terendah 40. Hasil pretest siswa kelas IX B sebagai kelas kontrol menunjukkan nilai rata-rata hasil belajarnya adalah 52 dan digolongkan nilai katagori rendah dengan nilai tertinggi 80 dan nilai terendah 30 .

Dari data hasil pretets siswa kelas eksperimen dan kelas kontrol menunjukkan bahwa nilai rata-rata siswa masih di bawah nilai Kriteria Ketuntasan Minimal (KKM) yaitu 75. Rendahnya nilai rata-rata hasil belajar siswa disebabkan beberapa hal di antaranya adalah belum adanya motivasi dan minat siswa untuk belajar mandiri selama masa Pembelajaran Jarak Jauh (PJJ).

Setelah dilakukan pembelajaran daring dengan mengunakan media Quipper School pada kelas eskperimen dan pemberian tugas melalui Whats App Group (WAG) pada kelas kontrol, siswa diberikan tes akhir atau postes untuk kedua kelas tersebut. Tes akhir ini dimaksudkan untuk mengetahui apakah media Quipper School lebih interaktif dan efektif dibandingkan dengan pemberian tugas melalui Whats App Group (WAG).

Tabel 4 Hasil Belajar Siswa Setelah Perlakuan ( Post-test )

\begin{tabular}{|c|l|c|c|}
\hline No & \multicolumn{1}{|c|}{ Statistik Deskriptif } & Kelas Kontrol & Kelas Eksperimen \\
\hline 1 & Jumlah Sampel & 31 & 31 \\
\hline 2 & Skor tertinggi & 85 & 96 \\
\hline 3 & Skor terendah & 40 & 68 \\
\hline 4 & Rata-rata & 70 & 85 \\
\hline
\end{tabular}

Hasil post-test di kelas eksperimen (IX D) menunjukan bahwa nilai rata-rata hasil belajar siswa adalah 85 dengan nilai tertinggi 96 dan nilai terendah 68. Sesuai hasil postes siswa kelas eksperimen menunjukan nilai rata-rata siswa telah memenuhi KKM. Sedangkan kelas kontrol (IX B) nilai rata-rata 70 dengan nilai tertinggi 85 dan nilai terendah 40. Peningkatan hasil belajar di kelas eksperimen disebabkan media Quipper School yang digunakan merupakan media yang tepat. 
Media ini menyediakan fasilitas diskusi sehingga siswa dapat bertanya jawab kepada guru kapan saja. Media ini selain interaktif dan efektif juga berbasis internet yang memiliki fitur menarik dan menyenangkan, sehingga dapat merangsang siswa dalam belajar dan membantu meningkatkan hasil belajarnya.

Setelah mendapatkan hasil belajar siswa, peneliti kemudian melakukan uji normalitas data, uji homogenitas, uji regresi sederhana, dan uji hipotesis.Penelitian ini uji normalitasnya untuk kelas yang diajar dengan media Quipper School dan kelas tanpa diajar quipper school menngunakan program SPSS versi 16 for windows bertujuan untuk mengetahui data yang diteliti apakah data yang diperoleh dari responden berdistribusi normal atau tidak. Dengan menggunakan metode Kolmogorov Smirnova dan Shapiro-Wilk pada taraf signifikansi $\alpha=0,05$ untuk data sebanyak 31 siswa .

1. Uji Normalitas

Tabel 5 Hasil IUji Normalitas

\begin{tabular}{|l|l|c|c|}
\hline No & \multicolumn{1}{|c|}{ Kelas } & Kolmogorov- Smirnova & Shapiro-Wilk \\
\hline 1 & $\begin{array}{l}\text { Kelas IX D ( yang diaajar } \\
\text { QUipper School }\end{array}$ & Sig $=0,022$ & Sig $=0,019$ \\
\hline 2 & $\begin{array}{l}\text { Kelas IX B ( yang tidak } \\
\text { diajar quipper school })\end{array}$ & Sig=0,165 $=0,12$ \\
\hline
\end{tabular}

Berdasarkan nilai signifikan pada kelas yang diajar dengan Quipper School menggunakan metode Kolmogorov Sminova diperoleh nilai signifikan 0,022 lebih besar dari 0,05 ( ig $>0,05$ ) maupun dengan metode Shapiro-Wilk diperoleh nilai signifikan sebesar 0,019 lebih besar dari 0,05 (sig >0,05), maka dapat disimpulkan bahwa data tersebut berdistribusi normal.Demikian juga dari kelas yang tidak diajar menggunakan Quipper School nilai signifikan dengan metode Kolmogorov Sminovadiperoleh nilai signifikan sebesar 0,165 lebih besar dari 0,05 (sig >0,05) maupun dengan metode Shapiro-Wilk diperoleh nilai signifikan sebesar 0,12 lebih besar dari 0,05 (sig >0,05), maka dapat disimpulkan bahwa data tersebut juga berdistribusi normal.

2. Uji Homogenitas

Tabel 6 hasil Uji Homogenitas

\begin{tabular}{|c|c|c|c|}
\hline Lavene statistic & Df1 & Df2 & Sig \\
\hline 0,638 & 3 & 25 & 0,598 \\
\hline
\end{tabular}

Berdasarkan data tersebut dengan memilih salah satu statistic yang didasarkan pada ratarata. Jika nilai signifikan yang diperoleh lebih besar dari 0,05 , maka varians setiap sampel sama (homogeny). Dari data di atas dapat disimpulkan bahwa signifikan 0,598 lebih besar dari 0,05, maka dapat dikatakan varians setiap sampel sama (homogeny). 
3. Uji Hipotesis

Uji hipotesis bertujuan untuk mengetahui ada pengaruh yang signifikan antara penggunaan media quipper dengan Whaps App (WA). Hasil uji menunjukan bahwa semua data berdistribusi normal dan data dari kedua kelas mempunyai varians yang homogeny. Berdasarkan data $\mathrm{T}$ hitung $<\mathrm{T}$ table $(0,598>0,366)$ sehingga Ho diterima dan Ha ditolak. Maka dapat disimpulkan bahwa media Quipper School lebih baik dari Whats Apps dan berpola linear. Hal ini juga berarti pembelajaran bahasa Indonesia dengan menggunakan media Quipper School pada masa pembelajaran jarak jauh pada siswa SMP Negeri 3 Cepu dapat meningkatkan hasil belajar siswa.

Penelitian ini membuktikan bahwa media Quipper School dapat meningkatkan hasil belajar siswa di masa pandemik ini. Siswa menjadi lebih mandiri karena siswa dapat belajar mencari materi pelajaran melalui media Quipper School. Penerapan media pembelajaran Quipper School membentuk kemandirian belajar siswa, yang dilakukan dengan memempatkan media Quipper School sebagai alternatif pembelajran untuk memantau dan menilai kompetensi pengetahuan siswa melalui online. Selain itu, melaui media Quipper School siswa akan lebih mandiri lagi untuk mencari materi tambahan yang ada di media Quiiper School sehingga hasil belajar siswa menjadi lebih baik lagi. Seperti penelitian yang dilakukan oleh Asri et all (2016) dengan judul penelitian "Pengaruh Penerapan E-Learning Quipper School terhadap Kemandirian Belajar Siswa di SMA Negeri 109 Jakarta", dengan hasil penelitian terdapat pengaruh penerapan Quipper School terhadap kemandirian belajar siswa. Hal ini ditunjukkan dengan hasil postes siswa lebih baik dari pretest. Sementara kelas yang diberi tugas dengan media Whats App peningkatan hasil belajar hanya sedikit dikarenakan dalam media Whats App tidak ada fitur-fitur untuk melatih siswa mengerjakan soal atau mencari materi pembelajaran.

\section{PENUTUP}

\section{Simpulan}

Berdasarkan hasil penelitian dan analisis data yang telah dilakukan maka dapat disimpulkan sebagai berikut.

1. Penerapan Media Quipper School dapat membantu guru dalam menentukan media yang tepat untuk pembelajaran jarak jauh. Dalam media Quipper School menyediakan bahan ajar yang menarik sesuai kurikulum 13, siswa dan guru dapat berdiskusi melalui media ini, sehingga siswa menjadi lebih aktif. Ada dua portal dalam media Quipper School ini,kapan pun guru bisa memberi tugas dengan mudah dan siswa dapat mengerjakan tugas pada saat itu juga.

2. Melalui penelitian dan pembahasan mengenai penggunaan media Quipper School untuk meningkatkan hasil belajar siswa yang dilakukan selama pembelajaran jarak jauh (PJJ) menunjukkan meningkatnya nilai pretes 61,94 ke postes yaitu 78,90 pada kelas eksperimen (IX D). Dengan demikian dapat diketahui bahwa penerapan media Quipper School dapat meningkatkan hasil belajarsiswa kelas IX di SMP Negeri 3 Cepu. 


\section{Saran}

Saran yang dapat disampaikan dari hasil penelitian ini adalah

1. Hasil penelitian ini diharapkan sebagai masukan bagi kepala sekolah untuk memperlancar kegiatan pembelajaran secara daring sehingga hasil belajar siswa meningkat.

2. Kepada guru hasil penelitian ini dapat dijadikan masukan untuk memanfaatkan media yang tepat seperti Quipper School agar hasil belajar siswa tetap meningkat di masa pandemi Covid19.

3. Kepada siswa dengan hasil penelitian ini bermanfaat untuk meningkatkan motivasi belajar siswa dengan menggunakan media Quipper School.

4. Semoga penelitian ini bermanfaat bagi peneliti lainnya dengan melakukan penelitian yang lebih luas. 


\section{DAFTAR PUSTAKA}

Aprilianto, R., \& Putra, M. 2020. Kendala Pelaksanaan Pembelajaran Jarak Jauh ( PJJ) dalam Masa Pandemi. April (Diakses 20 September 2020 )

Arizona, Kurniawan. et.all. 2020. Pembelajaran Online Berbasis Proyek Salah Satu Solusi Kegiatan Belajar Mengajar di Tengah Pandemi Covid-19 . Jurnal Ilmiah Profesi Pendidikan. Volume 5 No 1 Mei 2020. (Online) Tersedia

https://jipp.unram.ac.id/index.php/jipp/article/download/111/99. DOI: 10.29303/jipp.v5i1.111 (Diakses 21 Oktober 2020)

Barlian, Eri 2016. Metodologi Penelitian Kualitatif \& Kuantitatif. Padang : Sukabina Press.

Hudaidah, S. . (2019.). Pengaruh Media Pembelajran Quipper terhadap Hasil Belajar Siswa Kelas XI pada Mata Pelajaran Sejarah di Madrasah Aliyah. 2-17. Criksetra Jurnal Pendidikan Sejarah 8(1), Maret 2019 (Diakses 19 Agustus 2020)

Hukum, D., Pendidikan, P., Jenderal, S., \& Dasar, P. (2020). Pedoman Penyelenggaraan Belajar dari Rumah dalam Masa Darurat Penyebaran Corona Virus Disease (COVID-19). 021.

Karmila, Nining (2017). Pengaruh Penggunaan Media Pembelajaran Quipper School Terhadap Minat Belajar Fisika Siswa. Jurnal Pendidikan Fisika, 5(2), 120-127. https://docplayer.info/52011800-Pengaruh-penggunaan-media-pembelajaran-quipperschool-terhadap-minat-belajar-fisika-siswa-sma-negeri-10-bulukumba-skripsi.html (Diakses 19 Agustus 2020)

Sugiyono. (2012). Metode Penelitian Kuantitatif, Kualitatif, dan Tindakan. Bandung: Alfabeta. 